\title{
PEDAGOGIES TOWARDS ENHANCING STUDENTS' INTELLECTUAL CAPITAL IN MALAYSIAN SECONDARY SCHOOLS
}

\author{
Nor Asniza Ishak* and Hazri Jamil \\ School of Educational Studies, Universiti Sains Malaysia, \\ 11800 USM Pulau Pinang, Malaysia \\ *Corresponding author: asnizaishak@usm.my
}

Publication date: 23 December 2020

To cite this article: Nor Asniza Ishak, \& Hazri Jamil. (2020). Pedagogies towards enhancing students' intellectual capital in Malaysian secondary schools. Asia Pacific Journal of Educators and Education, 35(2), 57-76. https://doi.org/10.21315/apjee2020 .35 .2 .4

To link to this article: https://doi.org/10.21315/apjee2020.35.2.4

\begin{abstract}
This research explores the pedagogical practices among secondary school teachers in enhancing students' intellectual capital. Pedagogical practices measured were from the aspects of teaching plans/design of teaching, teaching strategies and evaluation of teaching. This study aims to obtain insightful information with regards to the current pedagogical practices that enhancing students' intellectual quality in Malaysian secondary school classroom and to further identify the best pedagogical practices for enhancing the students' intellectual quality. This research employed qualitative research design which is adapted to obtain data and information. Qualitative study was carried out involving interview of 10 teachers selected from different schools located at different zone in Malaysia based on certain criteria set by the researchers. A thematic analysis method was used for qualitative data. Findings of this study showed that teachers use a variety of approaches, methods and techniques in teaching and learning process that enhanced the students' intellectual quality through questioning techniques, intellectual discussion and debate, associating content with students' real-world experience and affective aspects in teaching and learning. Based on these findings, creativity, innovation and teachers' affective aspects were important elements in implementing pedagogical practices in enhancing the students' intellectual quality.
\end{abstract}

Keywords: Pedagogical practices, intellectual quality, Malaysian secondary schools, quality education, human capital 


\section{INTRODUCTION}

In Malaysia, the government committed to provide quality education, vis-à-vis to make Malaysia as a centre of educational excellence (Ministry of Education Malaysia, 2015) is a central feature of educational policy and practices from the top level of educational institutions to the bottom level in the policy and curriculum implementation. In this context, school is an important place to realise the educational aims in enhancing the education quality and developing human capital of the nation. In relation, there is a growing acceptance that we are living in an era, in which the need to address complexities, uncertainties and changing understanding of education, teaching and learning is important (Lingard et al., 2003; Ishak, 2015). Furthermore, the information technology and multimedia are increasingly shaping how we teach, learn and thinking. Teachers in Malaysia are grappling with these issues and this has also contributed to the needs for finding the best strategies to transform and disseminate knowledge, skills and thinking and values in education. In addressing such complexities, challenges and quality in education, the effort to enhance and improve teacher quality and learning outcomes, especially through pedagogical practices in classroom is important aspect to achieve national educational aims and facing global challenges in education.

Pedagogical practices in school need to address the complexities of rapid changing Malaysian society, different educational environments. The pedagogical practices in Malaysian school also need to meet the changing scenario in economic, social and technologies and market demands towards educational outcomes especially in the intellectual quality of the student (Ministry of Education Malaysia, 2015).

In dealing with the recent phenomena of Malaysia society, economic development and the affected of global demands to national education system, the pedagogical practices in classroom need to be investigated to find the best pedagogy strategies that could improve and sustain the quality of Malaysia education to pursuit the national educational aims and global demands on human capital in term of skill, knowledge and thinking quality. However, the flow of the intellectual development of students in education institutions seem not encouraging and alarming (Csikszentmihalyi, 2014). This situation gives rise to stagnation in the development of knowledge and intellectual development in the era of science and technology. Intellectual development of students considered necessary because the student is a major contributor to the country's workforce. Students in and beyond the 21 st century education changes need to think critically, creatively, 
critically and analytically. The intellectual level must be applied and shared by all students as intellectual aspects should be inculcated to all students since the school level (Yusliza, 2011).

This study will investigate pedagogical practices amongst Malaysian teachers in secondary schools which consist of: (i) teaching plans/design of teaching; (ii) strategy of teaching; and (iii) evaluation of teaching. A fundamental element of this research is its emphasis on classroom practices through the application of an observation instrument that incorporates the standards of authentic instruction (Newman \& Associates, 1996). This will inform the research, communities and practitioners for developing framework of pedagogies for intellectual capital for the Malaysian teachers in secondary schools.

Hence, the development of such framework of the pedagogies for enhancing student's intellectual capital which incorporate the best practices, strategies and method of teaching and learning process in classroom is important as a benchmark for Malaysian teachers to improve their pedagogies practices in contributing to the educational outcome of intellectual human capital development. Accordingly, the need to find a new perspective towards pedagogical practices in classroom for achieving quality and enhancing intellectual capital of the student are important to develop the human capital via Malaysian schooling system. With reference to the pedagogical practices in Malaysia schools, their effectiveness in achieving educational aims in relation to student's intellectual capital is still questionable. Several questions arise: What is really happening in our classroom? What is the expectation towards Malaysian teachers' pedagogical practice in classroom in developing and enhancing student's thinking skills? What are the best pedagogical practices that teachers, policy-makers, the communities and the learners expect for in changing age of national and global demands, especially in the aspect of intellectual capital?

\section{Research Objectives}

1. To obtain insightful information with regards to the pedagogical practices for enhancing students' intellectual quality.

2. To identify the best pedagogical practices for enhancing student intellectual quality. 


\title{
Research Questions
}

1. How teachers enhance students' intellectual quality in their pedagogical practices in the classroom?

2. What is the best pedagogical practice for enhancing student intellectual quality in the context of Malaysian secondary school classroom?

\section{LITERATURE REVIEW}

\section{The Pedagogies for Enhancing Intellectual Capital}

Intellectual capital is a term commonly associated with a business organisation's ownership of intangible assets which bring competitive advantage in term of knowledge gain and enhancing social capital to the organisation (Neary \& Hagyard, 2010; Sahlberg \& Oldroyd, 2010; Sveiby, 1997; Stewart, 1997). This includes skills, knowledge and information as well as deep social capital available to the company through the combination of its human and structural resources (Lengnick-Hall, Beck, \& Lengnick-Hall, 2011; Edvinsson \& Malone, 1997). Sveiby (1997) explained the term more descriptively by analysing the term intangible assets into three categories namely employee competence (education, experience), internal structure (the organisation: management, legal structure, manual systems, attitudes, R\&D, software), and external structure (brands, customer and supplier relationships). Petty, Cuganesan, Finch and Ford (2009) concluded that:

\begin{abstract}
Over time, a broad consensus has developed that intellectual capital can be characterised in terms of a tripartite model comprising human capital, external capital and internal capital components, where human capital refers to the skills/competences, training and education, and experience and value characteristics of an organisation's workforce; external capital comprises relationships with customers and suppliers, brand names, trademarks and reputation; and internal capital refers to the knowledge embedded in organisational structures and processes, and includes patents, research and development, technology and systems.
\end{abstract}

The success of national development objectives is highly dependent on the quality of human capital in terms of intellectual property. And intellectual ability to think critically and creatively in students has long been a goal of formal education 
(Maizan, 2017; Ministry of Education Malaysia, 2015; Ishak, 2015). Intellectual level should be increased in producing a critical, creative, critical, analytical and innovative human capital. In the level of macro strategy of Malaysian education development, Ministry of Education Malaysia has already set the goal of high intellectual development aims to produce human capital critically and creatively through the implementation of school curriculum (Ministry of Education Malaysia, 2013). Critical and creative force should be developed to the optimum level so that students are able to produce creative and quality ideas and inventions, and thus can become the practice and culture in the lives of Malaysians in the future. Individuals with high intellectual quality is a national asset who capable of contributing towards the development of society, community, nation and religion. At the tertiary level, the quality of students who are equipped with critical features such as innovation, critical thinking actually directly helps Malaysia become a developed nation by 2020 (Yusliza, 2011). Wadsworth (2004) with similar view affirmed that the main purpose is to strengthen tertiary education thinking person to a maximum level of thinking that one is innovative, creative and imaginative.

In the mass schooling system, which contribute to the development of human capital of the nation, pedagogy is the central feature of teachers' practices which make the most significant impact upon student development in term of their capitals of social, knowledge, skills and thinking. Pedagogy is the art of teaching. It is a central to professional knowledge and identities of teachers, as well as the central component of their practices in their profession. Coleman et al. (1966) and Lingard (2007) noted that, pedagogies are the most significant element of schooling in respect of student outcomes and refers to strategies of instruction, or a style of instruction. Rose and Martin (2012) considers that pedagogy is to construct a transmission of knowledge which attempts to strike a balance between the traditional approach and the constructivist approach with its emphasis on both teaching and learning and the theoretical focus on pedagogies is related to schooling process. The effectiveness of knowledge transmission and dissemination through instructions or teaching strategies (pedagogy) is important in order to achieve maximum learning outcome in overall aspects of education, including intellectual aspect (Rose \& Martin, 2012). In this sense, teachers and their classroom practices are the most significant factors for ensuring the productive educational outcomes, especially in relation to school performance and educational quality. Research in Malaysia indicates that the teachers' pedagogical practices in classroom are amongst the factors for the students' performance (Aminah, Hazri, Halim, Maznah, \& Farouk, 2004). Therefore, this ought to be one important focus of educational research. Pedagogical issues involving their methodology and approach to teaching is still a major issue to be resolved among school teachers (Bahagian Pembangunan Kurikulum, 2011). 
Intellectual qualities are the ability needed by the students to be more successful and to excel as practitioners in academic, work and life (Falk \& Millar 2002; Lublin, 2003). Intellectual qualities can be applied or integrated into teaching and learning in the context of the subject of study (Kearns, 2001). Intellectual quality components emphasised in the students should have a deep understanding of a topic, issue or discipline of study in order to be associated with a topic, issue or other disciplines (Lingard, 2007). Lingard (2007) also argues that, students' thinking need to grow more divergent to allow students to compete in the future. This fact is seen in the context of relevant secondary students who will step into the realm of higher education that requires students to be more competitive. This is in line with the country's main intention contained in the goals and objectives of the Ministry of Education (MOE) that produce quality human capital in all aspects of life has a way of thinking and rational action, high civic consciousness and realise its role in the country, society and religion (Arshad \& Ab Malik, 2015). This is also supported by Kennedy and Odell (2014), stated that learning at secondary school level is a challenge that requires understanding and complex ideas to students.

In producing students with high intellectual level, contributions and active participation of teachers is very important, especially at the school level (McFadden \& Munns, 2002). Teachers should be confident with the selection of effective pedagogy in line with the objective of teaching for developing the intellectual level of the student. Boon (1997) argues that teachers have the ability to effectively communicate the subject matter, positive, creative and develop and build the strength of the intellectual, emotional and spiritual stability of students through a mix of approaches, methods, techniques and teaching strategies.

In this research, the pluralistic concept of pedagogy will be implied to indicate that there is no one true way of teaching and that appropriate pedagogies for particular contexts need to be determined by teachers, often in conjunction with their students, local communities, national and global needs.

\section{METHODOLOGY}

This study applied a qualitative approach to explore the teachers' pedagogical practices in enhancing the students' intellectual capital with specific samples as well as to identify the best pedagogical practices used by teachers in enhancing the students' intellectual capital in the context of Malaysian secondary school system. This research adapted eclectic approach to obtain data for the study that seeks to gain various and multiple type of information, knowledge and understanding 
to form the framework of pedagogies for enhancing intellectual capital among student in Malaysian secondary school system. For the purpose of in-depth study, the researchers conducted the semi-structure interview with teachers and students to gain the information to answer the research questions.

\section{Research Sampling Method}

The study uses multistage purposive sampling technique for teacher data collection (Creswell, 2014). Through this method, the population is divided into several groups and number of schools and teachers are randomly selected. According to Watt and van der Berg (2002), to ensure that the sample chosen is valid, the researcher is required to select sample randomly. Total of 10 teachers were selected for the interview sessions. Two teachers from different schools located at five different zones in Malaysia (North zone, Central zone, South zone, East zone, and Sabah and Sarawak zones) were selected randomly from each school thus represent the state. This method is to ensure the sample selected to represent all areas in the state and generalisation can be made. Table 1 shows the teachers' demographic information.

Table 1. Teachers' demographic information

\begin{tabular}{lccc}
\hline Teacher ID & Gender & Teaching experience & Subject taught \\
\hline Teacher A & Female & 26 years & Islamic Education \\
Teacher B & Female & 20 years & History \\
Teacher C & Female & 16 years & Bahasa Melayu \\
Teacher D & Female & 7 years & History \\
Teacher E & Male & 11 years & Mathematics \\
Teacher F & Female & 30 years & English \\
Teacher G & Male & 12 years & Economy \\
Teacher H & Male & 15 years & English \\
Teacher I & Female & 21 years & Chemistry \\
Teacher J & Female & 26 years & Biology \\
\hline
\end{tabular}

To handle the issue of subject vulnerability, an assent form with date and signature for the students and witness were given out to participants. The assent form includes information on what the study is about, what procedures to be performed, a statement that the student can choose whether to participate or withdraw at any given time without negative consequences, an invitation to ask questions any time, and name/phone number of whom to contact with questions. 


\section{DATA ANALYSIS AND FINDINGS}

The findings are reported on the research question of "how the practice of secondary school teachers enhance the quality of students' intellectual". The finding of this study is done through interviews of teachers. Qualitative data gained is to generate themes of data obtained from the interviews on pedagogical practices of teachers. In this section, the main findings will be discussed on secondary school teachers' pedagogical practices in improving the students' intellectual capital by the following subtopics: (i) teaching plans/design of teaching; (ii) strategy of teaching; (iii) evaluation of teaching; and (iv) the approach supports the increasing intellectual quality of students.

\section{Teaching Plans/Design of Teaching}

This section will report the findings from interviews and observations on teaching and learning relating to teaching practices in lesson plans that increase students' intellectual capital.

\section{Induction set}

Set induction is the priority of teaching plans from the teachers interviewed. Although the goal of teaching is not only focused on increasing intellectual quality of the student, a good induction set is considered important in increasing the interest of students during teaching and learning. For example, one teacher stated that he favours induction set during the start of his teaching that:

I plan my lessons and even though it may not directly be for increasing students' intellectual capital per se. But somehow as I teach, the teaching itself would lead towards that. In my teaching plans, induction set is vital to attract students towards the subject. (Teacher A)

Further observations show that effective induction techniques stimulate students thinking. For example, through questioning and teaching/learning tools through video display helps introduce students to a new topic. It helps with knowledge entry of student on a topic which will be taught.

I usually show them videos during history lesson on what I will be teaching in class. Afterwards, we will go through and recall what we have watched. I usually ask my students questions after a video session. (Teacher B) 


\section{Spontaneous idea}

Teachers interviewed stressed upon spontaneous idea during teaching and learning in increasing students' intellectual capital. In one interview, Teacher C responded when asked on teaching plans: "I don't plan much. The activities I conduct with students are very much spontaneous".

It was also observed in Teacher D and Teacher E whereby teachers spontaneously use certain techniques on a subject taught. Teacher D also responded that, "the ideas will come somehow when I am teaching".

\section{Content knowledge}

The findings from interviews and observations have found that one aspect is vital in the design of teaching, that is, content knowledge. Teachers need to have good knowledge of content in order to deliver teaching and learning more effectively taking into account the needs and interests of diverse students (Shulman, 1987). Teachers interviewed expressed their interest to ensure content knowledge. They will look for new knowledge, revise, have additional readings and ensure accurate facts related to content. Teacher E said, "I would find other related books as we read to learn more".

I will read first before entering class. Even though we might know about a topic, it is important to read more and do extra readings related to it. My students love to ask, so I always make sure I am well prepared. (Teacher F)

\section{Knowledge of teachers on students}

From the interview, it was found that teacher's knowledge on their students is an important element in teaching plans to increase student's intellectual capital. Teacher $\mathrm{G}$ explained the importance of knowing her students before starting a class.

I make sure I know their background and see their ability. A lot of them are from rural areas and not much exposure. It is important for teachers to guide them well. (Teacher G) 


\section{Teaching Strategy}

Teaching strategy that increases students' intellectual capital include various aspect:

1. Teaching method to challenge and encourage HOT skills among students.

2. Teaching for knowledge and students' understanding.

3. Teaching based on problem solving strategy.

4. Teaching which encourages pithy discussion.

5. Appropriate language used.

\section{Teaching method to challenge and encourage HOT skills among students}

The interviews show that majority of teachers encourage students to use HOT skills by challenging the way they think. Various ways are used in this interview: (i) questioning strategy, (ii) self-access learning and (iii) encourage analysis, synthesis and creating new ideas. Questioning strategy used by teachers being observed varies. Structured questioning techniques from low level to high level is one of questioning techniques practiced by teachers to improve students' higher order thinking skills. King, Goodson and Rohani (2012), suggested that low levels of questions asked first before high level questions is able to provide students some time to answer as every student has different abilities. This was stated by Teacher $\mathrm{H}$ to ensure that students acquire the knowledge content before asking questions.

I use HOT skills when questioning students. After explaining, I will ask them high level questions. (Teacher $\mathrm{H}$ )

I place much importance on asking low level questions first before high level ones. When students understand then I will proceed to high level ones. No point asking them high level ones when they do not understand. (Teacher $\mathrm{H}$ )

Teacher $\mathrm{H}$ explained that she uses Why, What, Where, When and How a lot when asking questions. Why and How are especially focused on to increase their understanding so that they can utilise higher order thinking skills in their analysis, synthesis and creating new ideas. 
Also, to increase thinking skills among students, self-access learning is also stressed upon. Teacher believe that by encouraging students to find own information to answer questions given is vital towards increasing their intellectual capital. Inquiry strategy through self-access learning helps students give original ideas.

For the task given, the students have to give their own ideas. They come up with new ideas themselves. Example divorce cases. They need to think how to solve this issue. And these ideas come from them originally. (Teacher I)

Finally, encouraging analysis, synthesis and creating new ideas through teaching and learning tools is also being observed among the teachers. Using these tools, teachers encourage students to make analysis and synthesis of information obtained from the material observed. From observation, it was found that the use of information technology (ICT) as a medium for teachers to encourage students to make the analysis and synthesis lessons taught is vital. Teachers $\mathrm{J}$, for example, used a video using computer and LCD to before explaining the lesson content.

I want you to see this video. Observe and jot down what you understand from this video. We will discuss later. (Teacher J)

After the video, the teacher held discussion session for question and answer among teacher and students. Questions asked were high level questions whereby students are to connect and make comparison on the topic.

\section{Teaching for knowledge and students' understanding}

For students to have an in depth understanding on the lesson content, teachers observed used questions and drills through contextual content with existing knowledge and students' experience. Questions involving current issues, existing knowledge and students experience are integrated with educational content. In addition, knowledge of content is also emphasised for students who love to ask questions. This is to increase their understanding and intellectual capital related to a subject learnt. One teacher for instance, said that he would ask a question and student will answer by explaining more about what is being presented by the teacher.

When I teach them through PowerPoint they seem to understand. But when I ask questions not all students can answer. That's why I love to ask them questions in class for them to understand better the concept taught. I give them lots of exercises by finding questions that can relate to the current topic. (Teacher I) 


\section{Teaching based on problem solving strategy}

This method includes task given to encourage self-inquiry and discussion as well as an instructional scaffolding strategy for deeper understanding of a topic. Teachers interviewed stated that they encourage problem solving activities related to a particular issue or scenario by providing task-related topics and encouraging discussion. For example, Teacher J give individual assignments to students and emphasised that student is able to perform the task well.

It is through tasks given. Usually I like to give individual task outside class and for them to present during lessons. I see their effort made by students and if they can present well, if not better than us. (Teacher J)

To ensure problem solving during a task, this study found that teachers apply scaffolding techniques to guide students towards solving a problem before they are left to do so themselves. This is done through a variety of techniques to stimulate students such as through questioning, guidance and provocation. King, Goodson and Rohani (2012), suggested that teachers can encourage students through scaffolding at the beginning and gradually hand over responsibility to the students to continue the teaching and learning session. This helps them to develop higher-order thinking skills.

I give guidance but the students need to be taught well at this phase. Example, I ask questions What is the significance of Chloroplast? They answer for photosynthesis. So, I ask them to answer in detail and train them to answer more accurately to a given question. (Teacher J)

\section{Teaching which encourages pithy discussion}

From this study, teachers are observed to provide intellectual discussion and debate towards increasing student's intellectual capital. Discussions involving teachers asking questions to stimulate students to think and express opinions (Stenberg \& Lubart, 1996). However, the teacher responds by giving a comment or add information to the ones given by students. This approach encourages thoughtful discussion and can be followed by presentation of ideas followed by a debate. This is done through a democratic approach whereby teachers are ready to accept the argument put forth by students. Teacher I said that, "I conduct discussion sessions in groups followed by presentations." 


\section{Appropriate language used}

The findings show that the use of correct grammar in subjects taught is being emphasised by secondary school teachers. The emphasis on the correct use of grammar is different according to the subjects taught. A history teacher would criticise directly when students use inappropriate terms related to history.

Yes, I always remind students to use the correct terms in history lessons. Through activities I can observe if they use the right terms and if they are wrong, I will alert and comment on them. (Teacher D)

\section{Teaching Assessment}

The study found that teachers apply teaching assessment practices directly and indirectly in the classroom. Indirect method includes questioning techniques. Direct method includes training and assignments. Teaching assessments practiced by teachers which increase student's intellectual capital are: (i) high level questioning; (ii) project based learning; and (iii) assessment based on research tasks given.

\section{High level questioning}

In high level questioning, teachers emphasise questions that could encourage students to analyse, synthesise and create. Teacher E for example use questioning techniques to his students.

I usually use HOT during questioning in my lessons. After explaining to them, I will then ask them high level questions. (Teacher E)

He includes "why" and "how" questions in stimulating students' higher order thinking skills. This is for students to understand more in depth a concept learnt and thus able to think analytically by analysing and synthesising the subject content. He would ask students to discuss for 10 minutes after a lesson before allowing them to answer questions. 


\section{Project based learning}

Teacher F stated that he likes to give to students' project based learning in the form of drama. This teacher will ask students to act in certain situations and students will come up with ideas to utilise different props and costumes using recycled materials. He stressed that when students were asked to implement a project, the students are able to do it properly.

So instead of just reading the text in drama, I ask them to act and come out with their own props, costume, and use recycled materials. Everything is recycled. And students perform well. (Teacher F)

\section{Assessment based on research tasks given}

Teachers will allow students to complete a task given followed by presentation in the classroom. Teacher I explains he conducts evaluation of students by giving assignments. Students will complete the tasks given by themselves and then present it in class. Teacher F, a MUET teacher explained that when students do the assignments, they discuss and find information in detail, more like researching on the work.

If the MUET topic is about health, they will do their research and discuss. If there are topics related to the ones I taught, I will make sure they know about this topic deeply. So they have to do research and also present their findings. (Teacher F)

\section{Methods that Strengthen Pedagogy}

The findings from the study also found some other aspects related to approaches of teachers to increase students' intellectual capital gained from interviews and observations during teaching and learning. Themes that are involved include: (1) personal touch; (2) open-mindedness of teachers. Personal touch in the form of value, giving positive feedback, caring, being a good listener and being responsible should be traits in every teacher to stimulate the students to think creatively (Krathwohl, 2002). 


\section{Personal touch}

To increase students' intellectual capital, aspects gained from interviews and observations isthat there is a good rapport between teachers and students, either openly in classroom or outside of classroom. This good rapport exists in the form of motivation and advice.

I believe in having a good rapport with students because it impacts them personally. For example, there was this student who excelled last year. He wasn't an A student at first as he was very restless in class. But when the incident of his house being burnt down, he has changed tremendously after providing him with guidance and motivation, and in the end, he came out A student excelling in his studies. (Teacher J)

\section{Open mindedness of teachers}

The findings show that open-mindedness is also one of the important aspects to improve students' intellectual quality. Without an open mind, teachers can be biased and would not respect the ideas and opinions of students. Open mindedness, according to the Goodwin (2003), leads to empathy. This is explained by Teacher B that teachers need to be open when the student's questions lesson content and will discuss with students to answer their queries.

I don't avoid. I am open minded type. If a student thinks I am wrong, I will ask them where I did wrong and any idea to improve my teaching. I discuss with them, and if I can't answer their questions, I will discuss with other teachers and answer them afterwards. (Teacher B)

In conclusion, from interview, observation and document analysis, pedagogy practices to increase student's intellectual among secondary school teachers are different from teaching approach, strategy and technique used. Teachers incorporate various approach and techniques in building teaching and learning atmosphere towards increasing student's intellectual quality. From the research, it is shown that apart from implementation and emphasis on cognitive aspect, affective element also plays an important role in teaching pedagogy to increase student's intellectual quality. Elements include personal touch, open mindedness of teachers which motivate students and the adopted stimulus during teaching and learning can increase student's confidence in their thinking skills and challenge them to be more creative and critical. 


\section{DISCUSSION AND CONCLUSION}

This research has successfully reached its objectives. The main finding of this study is that secondary school teachers' pedagogy practices improve students' intellectual through various techniques and teaching approaches which are influenced by demography factor among teachers which include years of experience and the subject taught. Creativity, innovation and affective aspect of teachers are important elements in carrying out the specific teaching pedagogy practices to improve students' intellectual capital. This has been the main finding for this study to show the role of teachers to plan, implement and evaluate effective teaching to actively engage students in learning, i.e. through activities, discussions, asking questions, providing opinions and solving problems using higher order thinking skills. Teachers also need to be open minded and provide opportunities for students to submit ideas/insights to encourage them to expand their thinking scope and thus think intellectually. As stated by Simon, Erduran and Osborne (2006) and Barell (1991), in order to create an environment that encourages teachers and students to use their minds in the classroom, teachers and students need to undergo a process of change, something that involves not only learning new strategies, but also developing their role, examining their strength and commitment, and experiencing a variety of feelings of doubt and despair before reaching a feeling of satisfaction. This implies that the interaction between teachers and students is vital in the success of pedagogy towards improving students' intellectual capital.

Besides, this study has various implications: Implications on teaching practice, implications on teacher education and implications on theory. From this research, information and knowledge related to the practice dimensions in pedagogy to improve intellectual quality and implementation in the classroom by secondary school teachers can be shared. From interview and observation findings on teaching and learning, teaching methods and techniques to be used in classroom, as well as appropriate teaching evaluation are obtained. These findings were used to build a framework of good pedagogical practices in increasing intellectual quality of students. Conceptual framework can be used by secondary school teachers to instill intellectual quality during teaching and learning.

At the same time, this research provides proper understanding on the need of mechanism to increase secondary school teaching quality. Teachers who apply affective pedagogy in lessons are able to produce excellent students in terms of intellectual quality. This aspect should be emphasised by schools for teachers to be given the exposure in pedagogical practices to improve students' intellectual quality and dimensions involved through seminars and workshops. 
Pedagogical practices to increase intellectual quality among students could be still rather new in Malaysia. Thus, it is important for the stakeholders to provide training for teachers to expose them further on pedagogical practices towards increasing students' intellectual quality. It is important that teaching and learning environment in schools are well monitored for ensuring students are molded in a way where they are able to think creatively and critically and use their thinking skills to create ideas and analyse data. Information obtained from this study can be used to improve the quality of teaching and learning based on the conceptual framework for teachers' best pedagogical practices in improving intellectual quality of students through training workshops or seminars. Instilling intellectual qualities in students could help students to excel academically and make them better prepare entering university and work life.

Scientists often associate intellectual thinking with cognitive domain. However, this study showed that both affective domain and cognitive domain are needed in producing students who are able to think critically, creatively, analytically, communicate effectively and able to problem solve. From the findings of this study, affective domain was identified in pedagogical practices of teachers to encourage higher-order thinking among students. This is done through motivation, encouragement and stimulus for students to use the intellectual elements in teaching and learning. The motivation provided by teachers is in the form of personal touch and open-mindedness in ensuring that students are ready to comment, provide opinions and arguments for any problems arising. Thus, researchers interested in areas related to the intellectual development of students, should take into account theories and models of affective domain and cognitive domain — to be combined in order to better support the findings.

As a conclusion, it is hoped that the information obtained from this study could provide understanding and knowledge to teachers and researchers. Intellectual thought and pedagogical practices can be used to enhance the intellectual quality of secondary school students who are vital assets to the country in this 21 st century.

\section{ACKNOWLEDGEMENTS}

This research is funded by Universiti Sains Malaysia Research University Grant (Grant no. 1001/PGURU/816258). 


\section{REFERENCES}

Aminah Ayob, Hazri Jamil, Halim Ahmad, Maznah Ismail, \& Farouk Abdul Majid. (2004). A study of the causes of the failure among Malay students in academic achievement. Kuala Lumpur: Bahagian Penyelarasan Penyertaan Bumiputera, Prime Minister Department.

Arshad, M. N. M., \& Ab Malik, Z. (2015). Quality of human capital and labor productivity: a case of Malaysia. International Journal of Economics, Management and Accounting, 23(1), 37-55.

Bahagian Pembangunan Kurikulum. (2011). Buku panduan kreativiti: Pembangunan dan amalan dalam pengajaran dan pembelajaran. Putrajaya: Ministry of Education Malaysia.

Barell, J. (1991). Teaching for thoughtfulness: Classroom strategies to enhance intellectual development. New York: Longman Publishing Group.

Boon, P. Y. (1997). Amalan reflektif ke arah peningkatan profesionalisme diri guru. Jurnal IPBA, 3(2), 102-109.

Coleman, J., Campbell, B., Hobson, C., McPartland, J., Mood, A., Winefeld, F., \& York, R. (1966). Equality of educational opportunity report. Washington, DC: US Government Printing Office.

Creswell, J. W. (2014). A concise introduction to mixed methods research. SAGE publications.

Csikszentmihalyi, M. (2014). Applications of flow in human development and education (pp. 153-172). Dordrecht: Springer.

Edvinsson, L., \& Malone, M. S. (1997). Intellectual capital: Realizing your company's true value by finding its hidden brainpower. New York: Harper Collins.

Falk, I., \& Millar, P. (2002). Non/working lives: Implications of non-standard for higher education (GESIHE). Paper presented at Conference of the Pacific Rim Objective.

Goodwin, R. D. (2003). Association between physical activity and mental disorders among adults in the United States. Preventive Medicine, 36(6), 698-703. https://doi.org/10.1016/s0091-7435(03)00042-2

Ishak, N. A. (2015). Pedagogi guru prauniversiti dalam meningkatkan kualiti intelektual pelajar, Unpublished Doctoral dissertation, Universiti Sains Malaysia.

Kearns, P. (2001). Review of research: Generic skills for the new economy. Adelaide: National Centre for Vocational Education Research (NCVER).

Kennedy, T. J., \& Odell, M. R. L. (2014). Engaging students in STEM education. Science Education International, 25(3), 246-258.

King, F. J., Goodson, L., \& Rohani, F. (2012). High order thinking skills. Center for the Advancement of Learning and Assessment. Retrieved from https://informationtips.files.wordpress.com/2016/02/higher-order-thinkingskills_.pdf

Krathwohl, D. R. (2002). A revision of Bloom's Taxonomy: An overview. Theory into practice. 41(4), 212-218. https://doi.org/10.1207/s15430421tip4104_2 
Lengnick-Hall, C. A., Beck, T. E., \& Lengnick-Hall, M. L. (2011). Developing a capacity for organizational resilience through strategic human resource management. Human Resource Management Review, 21(3), 243-255. https://doi.org/10.1016/ j.hrmr.2010.07.001

Lingard, B. (2007). Pedagogies of indifference. International Journal of Inclusive Education, 11(3), 245-266. https://doi.org/10.1080/13603110701237498

Lingard, B., Hayes, D., \& Mills, M. (2003). Leading learning: Making hope practical in schools: Making hope practical in schools. McGraw-Hill Education (UK).

Lublin, J. (2003). Generic objectives and transferable skills: Centre for teaching and learning: Good practice in teaching and learning. Engineering Science and Education Journal, 8(4), 161-168.

Maizan, M. (2017). Teknik Mnemonik sebagai strategi kognitif dalam meningkatkan keupayaan ingatan pelajar peringkat pengajian pra-u: Sorotan kajian lepas. Selangor: Kolej Universiti Islam Antarabangsa Selangor.

McFadden, M. \& Munns, G. (2002). Student engagement and the social relations of pedagogy. British Journal of Sociology of Education, 23(3), 357-366. https://doi.org/10.1080/0142569022000015409

Ministry of Education Malaysia. (2013). Pelan Pembangunan Pendidikan Malaysia 20132025. Putrajaya: Ministry of Education.

Ministry of Education Malaysia. (2015). Pelan Pembangunan Pendidikan Malaysia 20132025. Putrajaya: Ministry of Education.

Neary, M., \& Hagyard, A. (2010). Pedagogy of excess: An alternative political economy of student life. In The marketisation of higher education and the student as consumer (pp. 209-223), Abingdon: Routledge.

Newman, F. M, \& Associates. (1996). Authentic achievement: Restructuring schools for intellectual quality. San Francisco: Josey Bass.

Petty, R., Cuganesan, S., Finch, N., \& Ford, G. (2009). Intellectual capital and valuation: Challenges in the voluntary disclosure of value drivers. Available at SSRN: https://doi.org/10.2139/ssrn.1490208

Rose, D., \& Martin, J. R. (2012). Learning to write, reading to learn: Genre, knowledge and pedagogy in the Sydney School. London: Equinox.

Sahlberg, P., \& Oldroyd, D. (2010). Pedagogy for economic competitiveness and sustainable development. European Journal of Education, 45(2), 280-299. https://doi.org/10.1111/j.1465-3435.2010.01429.x

Simon, S., Erduran, S., \& Osborne, J. (2006). Learning to teach argumentation: Research and development in the science classroom. International Journal of Science Education, 28(2-3), 235-260. https://doi.org/10.1080/09500690500336957

Sternberg, R. J., \& Lubart, T. I. (1996). Investing in creativity. American Psychologist, $51(7), 677$.

Stewart, T. A. (1997). Intellectual capital: The new wealth of organizations. New York: Doubleday.

Shulman, L. (1987). Knowledge and teaching: Foundations of the new reform. Harvard Educational Review, 57(1), 1-23. https://doi.org/10.17763/haer.57.1 .j463w79r56455411 
Sveiby, K. E. (1997). The new organizational wealth: Managing \& measuring knowledgebased assets. San Francisco: Berrett-Koehler.

Wadsworth, B. (2004). Piaget's theory of cognitive and affective development (5th ed.). Boston: Pearson.

Watt, J. H., \& van der Berg, S. (2002). Population and samples: The principle of generalization. In Research methods for communication science (pp. 50-61). Retrieved from http://ciosmail.cios.org:3375/readbook/rmcs/ch05.pdf

Yusliza Mohd Yusof. (2011). Minda intelek: AUKU melahirkan mahasiswa berfikiran kritis. Berita Harian. Retrieved 2 April 2013, from http://www.bharian.com. my/bharian/articles/MindaIntelek_AUKUmelahirkanmahasiswaberfikirankritis/ Article/index 